\title{
Relation between the rate of tumour cell proliferation and latency time in radiation associated breast cancer H Olsson*1,2, B Baldetorp ${ }^{1}, M$ Fernö ${ }^{1}$ and R Perfekt ${ }^{2}$
}

\author{
Address: ${ }^{1}$ Department of Oncology, University Hospital, SE-221 85, Lund, Sweden and ${ }^{2}$ Department of Cancer Epidemiology and South Swedish \\ Regional Tumour Registry, University Hospital, SE-221 85, Lund, Sweden \\ Email: H Olsson* - hakan.olsson@onk.lu.se; B Baldetorp - bo.baldetorp@onk.lu.se; M Fernö - marten.ferno@onk.lu.se; \\ R Perfekt - roland.perfekt@skane.se \\ * Corresponding author
}

Published: 9 April 2003

BMC Cancer 2003, 3:1 I
Received: 30 October 2002

Accepted: 9 April 2003

This article is available from: http://www.biomedcentral.com/I47/-2407/3/II

(C) 2003 Olsson et al; licensee BioMed Central Ltd. This is an Open Access article: verbatim copying and redistribution of this article are permitted in all media for any purpose, provided this notice is preserved along with the article's original URL.

\begin{abstract}
Background: Patients with possible radiation induced cancer could be used to study if the rate of tumour cell proliferation is related to latency time. Such a finding could help researcher to find time periods when other initiating risk factors operate.

Methods: Seventeen women with breast cancer, with a prior history of radiation treatment towards the parts or the whole breast, exclusive of the primary treatment of a breast cancer were identified. Most women had received treatment for benign disorders as hemangiomas, shoulder pain or skin infections. Three patients had been treated with mantle radiation for Hodgkin's disease prior to developing breast cancer. DNA analysis were performed, on remaining tumour tissue after hormone receptor analysis had been done, measuring the fraction of tumour cells in S-phase. Latency time (time between diagnosis and previous radiation treatment) was calculated and related to the S-phase fraction.

Results: A significant inverse relationship between latency time and S-phase was found ( $P<$ 0.0025 ), indicating that tumours with a high S-phase had a short latency time and vice versa. Among the possible radiation induced tumours, median $\mathrm{S}$-phase was $14 \%$, comparable with a median latency time of 22 years. Very high S-phase values were associated with short latency times (eg a S-phase of $35 \%$ would be compatible with a latency time of 7 years).

Conclusion: Our preliminary results indicate that S-phase is related to latency time and that the median latency time maybe as long as 22 years. Our data may also explain why breast cancer is rare before 30 years of age and if patients are diagnosed at early ages, tumours often show high S-phase values and bad prognostic signs. We postulate that these results from radiation induced breast cancer may be used to extrapolate possible latency times in patients with non radiation induced breast tumours in order to isolate possible time periods for research after other initiating events.
\end{abstract}

\section{Background}

Ionizing irradiation is the only proven initiating factor for human breast cancer. As such the breast, the thyroid, and the bone marrow appear especially radiosensitive[1]. By 
investigating several important cohorts of exposed women, as those surviving atomic bomb irradiation women given radiation therapy for the breast for acute post-partum mastitis or other benign diseases, and women examined repeatedly by fluoroscopy of the chest during treatment for pulmonary tuberculosis with artificial pneumothorax, our knowledge in the field of radiation induced breast cancer has increased[2]. Studies of patients, irradiated for benign conditions or other malignancies than breast cancer may help to describe latency times (time from the first initiating event to diagnosis) in human breast cancer. Studies of breast cancer after exposure to ionizing irradiation points to latency times between 10-30 years [3-5]. In general radiation exposures at very young ages have been associated with longer latency times for breast cancer than exposure at higher ages because radiation induced tumours generally first appear when the normal incidence of tumour is seen [6]. Excess risk has not appeared until 10 years after exposure and rarely before age $30[2,7-9]$. Also the relative risk of diagnosing a tumour seems to further increase in age groups where the natural incidence is high [6]. The risk has foremost and first been shown for women therapeutically irradiated at young ages (childhood, adolescence), while peri- and postmenopausal women irradiated for breast cancer in one breast have not conclusively been found to have a higher risk for contralateral breast cancer because of the radiation treatment $[10,11]$. This could be due to the fact that the breast epithelium at older ages is less sensitive due to involution and less proliferation.

Cases previously irradiated for benign conditions are becoming less common as the indications for irradiation of non tumour conditions are disappearing. We have previously described a case series in whom women in the past were irradiated for various benign conditions and other malignant diseases (as Hodgkin's disease)[12]. In that previous study, we found that cases with the progesterone receptor positive tumours more often had a history of therapeutic irradiation towards parts of or the whole breast after a pregnancy than before. Women with radiation treatment before the first pregnancy instead more often had progesterone receptor negative tumours.

The aim of the present study was to see if the S-phase fraction (SPF), knowing the age of the woman at diagnosis, could predict the possible latency time and thus give information at what age or age interval the tumour ought to have been initiated. If SPF could be used in such manner epidemio-logical studies using markers for proliferation in the tumour may assist the epidemiologist in designing studies aimed at identifying initiating factors of breast cancer in a relevant age period of life.

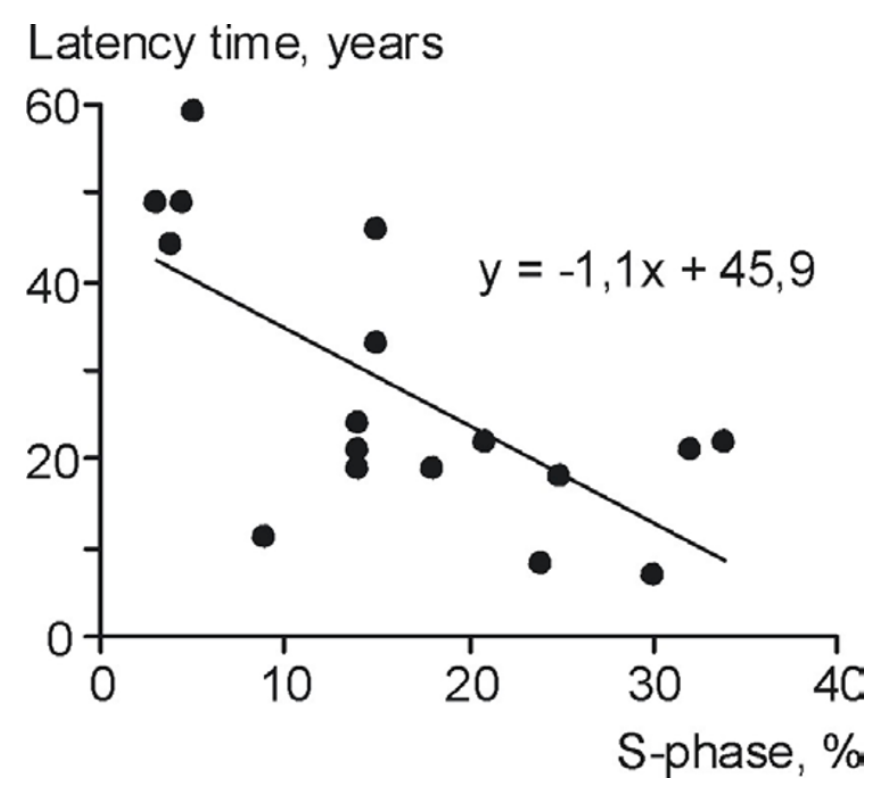

Figure I

\section{Methods}

Seventeen women with breast cancer, with a prior history of radiation treatment towards part of or the whole breast, exclusive of the primary treatment of a breast cancer, were identified. Fourteen women had received treatment for benign disorders as hemangiomas, shoulder pain or skin infections. Three patients had been treated with mantle radiation for Hodgkin's disease prior to developing breast cancer. The radiation dose to the breast tissue varied between 1-40 Gy. All women also had remaining tumour tissue stored at to our department after hormone receptor analysis had been done.

Flow cytometric DNA analysis (FCM) was performed according to the following protocol. Tissue was stored at $80^{\circ} \mathrm{C}$ and a nuclei suspension was prepared with a onestep procedure $[13,14]$ according to current protocol at our lab [15]: 100-200 mg of tissue per tumour sample was thawed in 100-200 ul of citrate buffer (sucrose 250 $\mathrm{mM}$, trisodium citrate $40 \mathrm{mM}$, dimethyl sulphoxide $5 \%$, $\mathrm{pH}$ 7.6) containing trout and chicken red blood cells $(106 / \mathrm{ml})$. The tissue was mechanically disintegrated with forceps and thereafter $2 \mathrm{ml}$ of a nuclear isolation medium containing propidium iodide (PI) was added (50 mg PI/ $\mathrm{ml}$, SIGMA P-5264; RNAse $0.1 \mathrm{mg} / \mathrm{ml}$, SIGMA R-5125; Nonidet P-40 0.6\% (v/v; SIGMA N-3516) in isotonic buffered saline; GIBCO). Before incubation in the dark (10 min at room temperature), the sample was filtered (nylon mesh $140 \mathrm{um}$ ) in order to remove tissue remnants from the obtained nuclei suspension. The samples were then 
kept at $+4 \mathrm{C}^{\circ}$ until the analysis. An Ortho $50 \mathrm{H}$ flow cytometer (Ortho Instruments, Westwood, Massachusetts, USA) was used for the nuclear DNA content analysis. The obtained DNA histogram distributions were judged either as DNA diploid (one cell population) or DNA non-diploid (two or more cell populations). By assuming the cell population to asynchroneously synthesizing the DNA, rectangular distribution, the fraction of cells in the $S$ phase (SPF) was estimated planimetrically according to Baisch et al [16]. In case of bimodality in the DNA diploid region reflecting near diploidy (hypo- or hyper diploidy) a mean SPF value was reported for both cell populations together. If DNA index of the non diploid cell population exceeded 1.3 the SPF was reported for this cell population alone. When two or more non diploid cell populations were seen (multiploidy) the SPF for the most prominent cell population was calculated. In those multiploid cases where the cell populations did not appear separated, a mean SPF value was calculated. SPF was not calculated if the histogram showed a debris distibution pattern grossly influencing the $\mathrm{S}$ phase region or the fraction of non diploid G0/ G1nuclei was less than $15 \%$ of all observed histogram events of the cell cycle. Furthermore, SPF was not reported for those cell populations lacking a visible G2 peak or the $\mathrm{CV}$ (coefficient of variation) of the G0/G1 peak exceeded $8 \%$. Aggregates from nuclei were gated out using the build in DNA analysis software of the Ortho 2140 data handling system.

Latency time (time between diagnosis and previous radiation treatment) was calculated and related to the SPF by regression analysis testing for a linear or a nonlinear relationship.

\section{Results}

Median age at radiation exposure was 34 years, range 172 yers and median age at breast cancer diagnosis was 64 years range 39-79 years.

The median SPF was 15 (range 3.0-34\%). Latency time varied with a median 22 years (range $7-59$ years)

A significant inverse relationship between latency time and S-phase was found ( $<0.0025)$, see Figure 1. A linear relation with latency time as the dependent variable and SPF as the independent variable best fitted the values, $\mathrm{Y}=$ $45.89-1.09 \mathrm{X}$, with a $\mathrm{r}^{2}=0.47$. An increase of one percent in S-phase decreased latency time on average with one year (95\% confidence interval $0.5-1.73$ years). A quadratic model gave a slightly better fit, $\mathrm{r}^{2}=0.60$, but in view of the small number of observations it was not possible to further explore the functional relationship in more detail and for the same reasons prediction intervals was not presented. Data visualised in Figure 1 suggested that a latency times less than 8 years was difficult to reach as well as SPF levels below 3\%.

No significant relationship was seen between radiation dose and latency time $(\mathrm{p}=0.30)$.

\section{Discussion}

The time of initiation of an individual breast cancer can only rarely be assessed. The only known exogenous exposure that can be used to possibly date the first initiating event of human breast cancer is ionizing radiation. The practise to treat benign disorders with radiotherapy was prevalent in the past but has become more and more uncommon during the last 30 years. Especially long term side effects as secondary tumors have discouraged the use of radiotherapy for non tumour diagnoses. This also means that the cohort of women, who previously has been exposed to ionising radiation treatment for benign diseases, is an "out dying" cohort and the time period when it is possible to use the cohort for important biological studies is gradually disappearing. In our setting we were fortunate to have a population based breast tumour bank for biological studies that was started 1979 where remaining tumour specimens after hormone receptor analysis have been saved as frozen specimens in $-80^{\circ} \mathrm{C}$.

Attempts have been made before to calculate latency times in breast cancer using various types of subpopulations as survivors of atomic bombs who later develop breast cancer and populations previously exposed to radiation treatment. The proposed latency time ranges from $10-30$ years $[1,17-19]$. However the increased risk after achieved minimal latency time seems to stay elevated throughout life [20].

By comparing the SPF with the latency time in our study a clear inverse relationship appeared. Our preliminary results indicate that by using the SPF it would be possible in larger materials to predict latency time and that the median latency time maybe as long as 22 years. In men with possible radiation induced breast cancer a possible latency time of 30-40 years have been suggested [4]. Also a minimum latency time of 8 years has been suggested out from radiation exposure studies and breast cancer [5]. In women, irradiated between the time of puberty and the age of 30 for Hodgkin's disease, a median latency time of 15 years have been seen $[21,22]$. Our results are not contradictory to these previous findings. The data may also explain why breast cancer is rare before 30 years of age as a tumour with a high SPF of $20 \%$ still would on average take 25 years to develop. Further data on SPF and latency time also give an explaination for findings of tumour biology in the very young women. For such a tumour to appear with a latency time less than 30 years there is a need to have a SPF above $20 \%$ and this tumour necessarily 
needs to show bad prognostic signs as a high SPF has been related to poor prognosis [23]. Studies on breast cancer prognosis in different age groups have especially singled out women below age 35 as having a worse prognosis than other women [24-26]. The breast tumours in patients with a prior history of Hodgkin's disease also seem to be more aggressive giving the patients a poorer survival in line with a possibility of higher SPF of their primary tumours because of the rather short latency time [27].

These latency times for radiation induced breast cancer accord very well with time studies of breast cancer development from atypical hyperplasia, through ductal carcinoma in situ and to invasive carcinoma, thought to require $10-20$ years or more $[28,29]$.

The median SPF in larger investigations at our laboratory is around $11 \%$ [30] compared to the result of the present investigation's 14\%. The variation can easily be explained by our small sample size of possibly radiation induced tumours. As the SPF varied between 3-34\% a difference in latency time between tumours could be as large as 7-59 years (median 22 years).

A shortcoming in our investigation is that while epidemiological data support that the group of patients may have radiation treatment as a risk factor it is impossible in the individual case to for certain know if radiation caused the tumour. We speculate that if we could accurately know which tumours that were radiation induced, the fit of the model would have been near perfect using the SPF.

We can not fully exclude that the model e.g. is quadratic rather than linear. More cases with biological data would be needed to fully describe the true relationship, but it is reasonable to believe that a minimal latency time of 5-10 years is required for a breast cancer to be able to develop. The reproducibility of analysing the SPF is in our hands very high $[31,32]$ and there is a high correlation with other measures of proliferation [33]. Further SPF calculations give very good prognostic information $[23,30]$. However there are sometimes potential problems as in patients with low SPF and multiple tumour populations calculations can be contaminated with normal tissue from tumour stroma or inaccuracies can occur in assessing the SPF because of overlapping tumour cell populations [30].

Other potential problems by our approach of relating the SPF to latency time is that cell loss/cell death in individual tumours could not be estimated or accounted for and may vary between tumours. Further it is not fully known from literature how human tumours grow eg if there is a contineous linear growth, exponential growths according to Gompertz or periods of interrupted exponential growths [34]. Further in experimental tumours there is a sugges- tion that a higher radiation dose may be related to a shorter latency time. However, this has been proposed to be due to a higher statistical probability for transformation at higher doses [35]. In the present study we did not see a statistical significant relationship between radiation dose and latency time, but the small sample size could have prevented us from finding a significant association. In general it has also been stated that radiation induced tumours in man tend to present at common ages for the incidence of a given tumour and thus be related to longer latency times if the radiation exposure took place at younger ages [36].

Most breast cancers are thought to start its development early in life at puberty or even in early childhood or in utero [37]. Previously, it has been proposed from one of the authors that the tumour at diagnosis, at least partially, retains characteristics of the normal breast epithelium at the time of initiation and that varying tumour biology/prognosis at different ages may be explained out from this $[38,39]$. Experience from atom bomb survivors suggest that reproductive factors and hormone use appear to act independently of radiation exposure on the risk of breast cancer among this population [40].

\section{Conclusion}

Results from radiation induced breast cancer may be used to extrapolate possible latency times in patients with non radiation induced breast tumours. Out from a woman's age at diagnosis and SPF, a possible latency time, using our linear formula, possibly can be predicted and initiating epidemiological risk factors can be sought in the responsible time period for initiation. This may enable researcher to more efficiently find new initiating risk factors of breast cancer. It is conceivable that other measures of tumour proliferation rate as mitotic index, labelling index, antibodies as Ki-67, or BrdU labelling may be used in a similar manner and this may allow studies on larger patient materials, where paraffin embedded tumour materials have been saved. These different measures of proliferation (such as S-phase, labelling index, mitotic index, Ki-67) have been found to correlate well with each other in breast cancer [41]. To calibrate curves between tumour proliferation rate and latency time, tumours from possibly radiation induced cases must be identified and used. Therefore radiation induced cases consitute a very important "out-dying" research source.

\section{References}

I. Ullrich R Etiology of Cancer:Physical Factors In: Cancer. Principles \& Practice of Oncology (Edited by: de Vita V, Hellman S, Rosenberg S) Philadelphia: Lippincott Williams \& Wilkins 200I, 195-206

2. Boice J, Land $C$ and Preston $D$ lonizing radiation In: Cancer Epidemiology and Prevention (Edited by: Schottenfeld D, Fraumeni J) New York: Oxford University Press 1996, 319-354

3. Thomas D Epidemiologic and related studies of breast cancer etiology In: Reviews in cancer epidemiology (Edited by: Lilienfeld A) New York: Elsevier/North-Holland 1980, 153-217 
4. Thomas DB, Rosenblatt K, Jimenez LM, McTiernan A, Stalsberg $\mathrm{H}$, Stemhagen A, Thompson WD, Curnen MG, Satariano W and Austin DF lonizing radiation and breast cancer in men (United States) Cancer Causes Control 1994, 5:9-14

5. Goss PE and Sierra $S$ Current perspectives on radiation-induced breast cancer / Clin Oncol 1998, 16:338-47

6. Upton AC Carcinogenic effects of ionizing radiation In: Mechanisms of carcinogenesis (Edited by: Weisburger EK) Dordrecht, Netherlands: Kluwer Academic Publishers 1989, 54-70

7. Tokunaga M, Norman JE Jr, Asano M, Tokuoka S, Ezaki H, Nishimori $I$ and Tsuji $Y$ Malignant breast tumors among atomic bomb survivors, Hiroshima and Nagasaki, 1950-74 J Natl Cancer Inst 1979, 62:1347-59

8. Kato $H$ Radiation-induced cancer and its modifying factor among A-bomb survivors Princess Takamatsu Symp 1987, I 8: I I7. 24

9. Ron $E$ lonizing radiation and cancer risk: evidence from epidemiology Radiat Res 1998, I 50:S30-4I

10. Boice JD Jr Radiation and breast carcinogenesis Med Pediatr Oncol 2001, 36:508-13

II. Jung $\mathrm{H}$ Is there a real risk of radiation-induced breast cancer forpostmenopausal women? Radiat Environ Biophys 200I, 40:16974

12. Olsson H, Sigurdsson H, Borg $\AA$ and Fernö M Relationship of progesterone-receptor positivity in malignant breast tumours to reproductive status of women at tumour initiation-results from patients with possible radiation induced tumours J Natl Cancer Inst 1990, 82:529-53 |

13. Thornthwaite J, Sugarbaker E and Temple W Preparation of tissues for DNA flow cytometric analysis Cytometry 1980, I:229237

14. Lee G, JT T and Rasch E Picogram per cell determination of DNA by flow cytofluorometry Analyt Biochem 1984, 137:221-226

15. Baldetorp B, Dahlberg M, Holst U and Lindgren G Statistical evaluation of cell kinetic data from DNA flow cytometry (FCM) by the EM algorithm Cytometry 1989, 10:695-705

16. Baisch H, Göhde $W$ and Linden W Analysis of PCP-data to determine the fraction of cells in the various phases of cell cycle Radiat Environ Biophys 1975, I 2:3 |-39

17. Hildreth $\mathrm{N}$, Shore R and Dvoretsky $P$ The risk of breast cancer after irradiation of the thymus in infancy N Engl Journ Med 1989, 32I: $|28|-\mid 284$

18. Modan B, Alfandary E, Chetrit $A$ and Katz $L$ Increased risk of breast cancer after low-dose irradiation Lancet 1989, i:629-631

19. Shore RE Electromagnetic radiations and cancer. Causes and prevention Cancer 1988, 62:1747-1754

20. Mattsson A, Ruden BI, Palmgren J and Rutqvist LE Dose- and timeresponse for breast cancer risk after radiation therapy for benign breast disease $\mathrm{Br}$ J Cancer 1995, 72: |054-61

21. Cutuli B, de La Rochefordiere A, Dhermain F, Borel C, Graic Y, de Lafontan B, Dilhyudy JM, Mignotte H, Tessier E, Tortochaux J, N'Guyen T, Bey P, Le Mevel-Le Pourhier A and Arriagada R [Bilateral breast cancer after Hodgkin disease. Clinical and pathological characteristics and therapeutic possibilities: an analysis of 13 cases] Cancer Radiother 1999, I:300-6

22. Clemons $M$, Loijens $L$ and Goss $P$ Breast cancer risk following irradiation for Hodgkin's disease Cancer Treat Rev 2000, 26:29|302

23. Wenger CR and Clark GM S-phase fraction and breast cancer a decade of experience Breast Cancer Res Treat 1998, 5 I:255-65

24. Höst $\mathrm{H}$ and Lund $\mathrm{E}$ Age as a prognostic factor in breast cancer Cancer 1986, 57:2217-2221

25. Adami H, Malker B, Holmberg L, Persson I and Stone B The relation between survival and age at diagnosis in breast cancer $N$ Engl J Med 1986, 3 I 5:559-563

26. Guinee V, Olsson H, Möller T, Hess K, Taylor S, Fahey T, Gladikov J, van den Blink J, Bonichon F, Dische S, Yates J and Cleton F Effect of pregnancy on prognosis for young women with breast cancer Lancet 1994, 343: 1587-89

27. Gaffney DK, Hemmersmeier J, Holden J, Marshall J, Smith LM, Avizonis V, Tran T and Neuhausen SL Breast cancer after mantle irradiation for Hodgkin's disease: correlation of clinical, pathologic, and molecular features including loss of heterozygosity at BRCAI and BRCA2 Int J Radiat Oncol Biol Phys 200I, 49:539-46
28. Frykberg E and Bland K In situ breast cancer Adv Surgery 1993, 26:29-72

29. Page DL, Dupont WD, Rogers LW and Rados MS Atypical hyperplastic lesions of the female breast. A long-term follow-up study Cancer 1985, 55:2698-708

30. Sigurdsson $\mathrm{H}$ Indicators of prognosis in breast cancer Oncology Lund: Lund 1990, 68

3I. Gudmundsson TE, Langstrom E, Alm P, Anderson H, Baldetorp B, Ferno M, Hogberg $T$ and Killander D Methodological aspects of flow cytometry DNA analysis in endometrial carcinoma, with special reference to sampling and reproducibility Acta Oncol 1996, 35:999-1006

32. Baldetorp B, Stal O, Ahrens O, Cornelisse C, Corver W, Falkmer U and Ferno $M$ Different calculation methods for flow cytometricS-phase fraction: prognostic implications in breast cancer? The Swedish Society of Cancer Study Group Cytometry 1998, 33:385-93

33. Rudolph P, Olsson H, Ratjen V, Bolte H, Baldetorp B, Fernö M, Parwaresch R and Alm P Correlation between p53, C-erbB-2, and topoisomeras II expression, DNA ploidy, hormonal receptor status and proliferation in node negative breast cancer. Prognostic implications J Pathology 1999, 187:207-216

34. Harris a and Hellman $S$ Natural history of breast cancer In: Diseases of the Breast (Edited by: Harris J, Lippman M, Morrow M, Hellman S) Philadelphia: Lippincott-Raven Publishers 1996, 375-391

35. Guess HA and Hoel DG The effect of dose on cancer latency period J Environ Pathol Toxicol 1977, I:279-86

36. Boice J Risk estimates for breast cancer In: Critical issues in setting radiation dose limits. Proceedings of the 7th Annual meeting 8-9th April: 7910 Woodmont Ave (Edited by: N. C. o. R. P. a. Measurements) Bethesda Md 208/4 |98I, |64-|8|

37. Kelsey J Epidemiology of breast cancer Epidemiol Rev 1993, I5: I236

38. Olsson $\mathrm{H} \mathbf{A}$ hypothesis about the tumour development and clinical picture in hereditary breast cancer Eur J Cancer 200I, 37:2023-2029

39. Olsson H Tumour biology of a breast cancer at least partly reflects the biology of the tissue/epithelial cell of origin at the time of initiation - a hypothesis The Journal of Steroid Biochemistry \& Molecular Biology 2000, 74:345-350

40. Goodman MT, Cologne JB, Moriwaki H, Vaeth M and Mabuchi K Risk factors for primary breast cancer in Japan: 8-year follow-up of atomic bomb survivors Prev Med 1997, 26: 144-53

41. Clark GM Prognostic and predictive factors In Diseases of the Breast (Edited by: Harris, JR, Lippman ME, Morrow M, Hellman S) Lippincott-Raven Publishers, Philadelphia 1996, 46I-485

\section{Pre-publication history}

The pre-publication history for this paper can be accessed here:

\section{http://www.biomedcentral.com/1471-2407/3/11/prepub}

Publish with Bio Med Central and every scientist can read your work free of charge

"BioMed Central will be the most significant development for disseminating the results of biomedical research in our lifetime. "

Sir Paul Nurse, Cancer Research UK

Your research papers will be:

- available free of charge to the entire biomedical community

- peer reviewed and published immediately upon acceptance

- cited in PubMed and archived on PubMed Central

- yours - you keep the copyright 